\title{
Long-term water balances in La Violada Irrigation District (Spain): II. Analysis of irrigation performance
}

\section{R. Barros, D. Isidoro and R. Aragüés}

Centro de Investigación y Tecnología Agroalimentaria de Aragón (CITA-DGA), Unidad de Suelos y Riegos (Unidad Asociada EEAD-CSIC), Avd. Montañana 930, C.P. 50059 Zaragoza, Spain.

E-mail: disidoro@aragon.es

Telephone: +34-976-716393; Fax: +34-976-716335

\section{Abstract}

The analysis of long-term irrigation performance series is a valuable tool to improve irrigation management and efficiency. This work focuses in the assessment of irrigation performance indices along years 1995 to 2008, and the cause-effect relationships with irrigation modernization works taking place in the 4000 ha surface-irrigated La Violada Irrigation District (VID). Irrigation management was poor, as shown by the low mean seasonal irrigation consumptive use coefficient (ICUC $=51 \%$ ) and the high relative water deficit $(\mathrm{RWD}=20 \%)$ and drainage fraction $(\mathrm{DRF}=54 \%)$. April had the poorest irrigation performance because corn (with low water demand in this month) was irrigated to promote its emergence, whereas winter grains (with high water demands in this month) were not fully irrigated in water-scarce years. Corn, highly sensitive to water stress, was the crop with best irrigation performance because it was preferentially irrigated to minimize yield losses. The construction of a new elevated canal that 
decreased seepage and drainage fractions, the entrance in operation of six internal reservoirs that would increase irrigation scheduling flexibility, and the on-going transformation from surface to sprinkler irrigation systems are critical changes in VID that should lead to improved ICUC, lower RWD and lower DRF. The implications of these modernization works on the conservation of water quantity and quality within and outside VID is further discussed.

Keywords: Evapotranspiration, irrigation management, consumptive use, water deficit, drainage fraction, water quantity, water quality.

\section{Introduction}

Part I of this work (Barros et al., 201x) presented a long-term, sequential water balance analysis in La Violada Irrigation District (VID) that identified and quantified the most important water balance components in this district. Based on these water inputs and outputs, Part II of this work calculates several irrigation performance indices for the assessment of water management as affected by irrigation improvements that have taken and will take place following irrigation modernization in VID.

Irrigation performance indices may help to quantify the beneficial and non beneficial uses of irrigation water (Molden 1997; Haie and Keller 2008). Based on the classical definition of irrigation efficiency given by Israelsen and Hansen (1962) as the fraction of irrigation water consumed by crops, several modifications that take into account hydrological issues have been developed (Keller and Keller, 1995; Burt et al. 1997; Seckler et al. 2003; Perry et al. 2009; Lecina et al. 2010; Perry, 2011). Rao (1993) made an extensive review on indicators of irrigation performance, summarizing and synthesizing the most useful indicators used in reports and publications. Jensen (2007) reviewed and summarized the evolution and recent modifications of the irrigation 
efficiency indices. Bos and Nugteren (1990) presented the most widely accepted concepts and definitions of irrigation efficiencies, defining various efficiencies associated with different components of the water delivery system. Bos et al. (1994) made a framework for assessing irrigation management and showed different methodologies for recommending performance indicators. Molden (1997) and Molden and Sakthivadivel (1999) endeavoured to create a common terminology for water accounting, distinguishing between water consumption and water delivery, and provided a guide of indicators for a better comparison of the performance of irrigation systems.

Many case studies on irrigation performance have been carried out using irrigation indices. Several were focused at the plot level in different crops, like rice (Humphreys et al. 2005), alfalfa (Hanson et al. 2007), and sunflower (Connor and Jones 1985), with the target of producing more with less water, whereas others were focused at the irrigation district level. Lorite et al. (2007) developed a model that simulates water balances and irrigation performances at the plot and irrigation district levels. Karatas et al. (2009) assessed the irrigation performance of several water user associations using remote sensing techniques to measure evapotranspiration from satellite data, and Krinner et al. (1994) presented a method for estimating efficiency in several Spanish irrigation systems. In the Ebro River Basin (North-East Spain), with more than 800000 ha of irrigated land, several studies analyzed irrigation efficiencies at the irrigation district level (Tedeschi et al. 2001; Cavero et al. 2003; Dechmi et al. 2003; Isidoro et al. 2004; Lecina et al. 2005; García-Garizábal et al. 2009; Lecina et al. 2010).

However, studies dealing with a long-term analysis of irrigation performance at the irrigation district level and its evolution with changes in crop patterns, irrigation practices, irrigation modernization and climatic variability are lacking. This work 
analyzes the irrigation performance in La Violada Irrigation District (VID), where water balances have been performed since the 80's. Faci et al. (2000) analyzed irrigation management in the hydrological year 1994 through the seasonal irrigation performance index (SIPI), defined as the seasonal percentage of the net irrigation requirements (NIR) to the volume of irrigation water delivered to crops. The average SIPI was $70 \%$, indicating that the volume of irrigation water was higher than the NIR. These authors concluded that irrigation management in VID was poor due to long irrigation intervals and delay times in water delivery, low ditch discharges (average of $69 \mathrm{~L} / \mathrm{s}$ ) and marginal areas with deficit irrigation which caused crop water stress.

Based on these conclusions, Playán et al. (2000) analysed different irrigation modernization scenarios where management and irrigation methods were modified with the goal of increasing irrigation efficiency. The best results were obtained for a SIPI of $77 \%$, which resulted in a reduction in diversions of $14.4 \mathrm{Mm}^{3} /$ year. This relatively high SIPI was obtained by a combination of blocked-end flood irrigation with an increased discharge of $200 \mathrm{~L} / \mathrm{s}$, and a change to sprinkler irrigation in areas where surface irrigation could not attain 50\% efficiency. Isidoro et al. (2004) analysed irrigation performances for the 1995-1998 hydrological years through a district-scale water balance. The seasonal average irrigation consumptive use coefficient (ICUC; Burt et al. 1997) was low (48\%) due to low distribution and delivery efficiencies. Furthermore, the actual crop evapotranspiration $\left(E T_{a}\right)$ was $16 \%$ lower than the maximum achievable crop $E T_{c}$ indicating that crop water-stress was significant in VID, in particular in areas with shallow and low water holding capacity soils.

Based on these and other studies performed in VID, several structural and management improvements detailed in the next section have taken place or will take place following the irrigation modernization in this district. This provides a unique 
opportunity to identify and quantify how these improvements affect irrigation water use by analyzing a continuous data base gathered in the district from 1995 to 2008 (i.e., before and after the implementation of these improvements).

The objectives of part II of the work performed in VID are to (i) analyze the water balance components and its evolution along fourteen irrigation seasons (1995 to 2008), (ii) assess irrigation performance through several crop, irrigation and drainage indices, and (iii) relate changes in these indices with improvements that have taken place during the last years in this irrigation district.

\section{Description of La Violada irrigation district (VID)}

VID is located in the middle Ebro River Basin (north-eastern Spain). The total surface of VID is 5282 ha, the irrigable land is about 4000, and the 1995-2008 average irrigated land was 3565 ha. VID is surrounded by the Monegros, Sta. Quiteria and Violada canals (Fig. 1), and it is integrated in the 57112 ha Monegros I irrigation scheme.

The climate of VID is Mediterranean, dry, subhumid and mesothermic, with precipitations concentrated in spring and autumn, and with maximum temperatures of $38^{\circ} \mathrm{C}$ in July and August. Mean annual values for the period 1995-2008 were $422 \mathrm{~mm}$ (precipitation), $14^{\circ} \mathrm{C}$ (temperature) and $1166 \mathrm{~mm}$ (ET , Penman-Monteith reference evapotranspiration).

The drainage system of the study area consists of a dense network of open ditches and buried pipe drains. There are two main drainage courses (Valsalada and Artasona ditches) that converge to make up La Violada Gully (Fig. 1). Since the district is underlain by an impervious clay stratum (Faci et al. 1985; ITGE, 1995), deep percolation is negligible and all or most drainage waters are intercepted and exported 
through this Gully, where a gauging station (D-14, Fig. 1) measures the flow of water exiting VID.

Faci et al. (2000) and Playán et al. (2000) presented a detailed description of the distribution system and irrigation management in VID. The district is irrigated from 11 turnouts in Monegros Canal, 16 in Violada Canal and 19 in Santa Quiteria canal. The most widely adopted irrigation system is flood-irrigation with blocked-end borders. The original delivery system was designed in the 1930's to supplement irrigation to winter cereals. The mean ditch capacity $(69 \mathrm{~L} / \mathrm{s})$ is insufficient to meet the crop water requirements of more water-demanding crops, like corn and alfalfa that developed in the 80's. This new crop pattern and the absence of any internal water storage capacity at that time forced the Almudevar Water User Association (CRA) to operate the system on a fixed-schedule, continuous basis (24 hours a day). Hence, distribution and on-farm efficiencies were poor and farmer's irrigation practices were laborious and problematic.

In the 80’s and 90’s CRA improved some conveyance structures (concrete lining and use of pipes in some irrigation ditches) and the Confederación Hidrográfica del Ebro (CHE) improved the rating curves and the accuracy of water delivery through the irrigation gates (Isidoro and Aragües, 2006). In the last decade, major structural and management improvements have taken place in VID related with the on-going Spanish modernization of irrigation districts, new water policies and increasing water-scarce years:

(i) Construction of the new elevated La Violada canal that replaced the old Canal seriously affected by seepage. The new canal rendered service in the 2003 irrigation season, eliminating its seepage and affecting the flow regime of La Violada Gully. 
(ii) Intense reuse of drainage waters for irrigation (around $2 \mathrm{hm}^{3}$ per year according to CRA) in years 1999, 2005 and 2006 by means of a new internal reservoir that collects the drainage waters of the Artasona ditch (Fig. 1).

(iii) Irrigation restrictions in years 1999 and 2005 due to severe water limitations following winter seasonal droughts.

(iv) Construction of six internal irrigation reservoirs with a total storage capacity of around $0.6 \mathrm{hm}^{3}$ that allow for a greater flexibility, changes from fixed to on demand irrigation, and increased irrigation efficiencies. Four small reservoirs with a total capacity of $0.2 \mathrm{hm}^{3}$ were operative since 1998 , whereas the remaining reservoirs will operate after the new pressurised irrigation systems will enter in service in 2010.

(v) Starting 2008, the flood irrigation systems are being transformed into pressurized system (mainly solid set sprinklers) through the commitments of the Spanish National Irrigation Plan (MARM, 2010). It is envisaged that this transformation will have a major impact on the water balance components and irrigation performance in the district.

Figure 2 presents the yearly irrigated area and the most important crops grown in VID (in percent of total irrigable land) during the 1995-2008 study period. During 1995-98 the most important crops were corn (50\% of total), alfalfa (21\%) and winter grains (13\%). Other secondary crops were rice, sunflower, orchards (pepper) and fruit trees. During 1999-2004 there was a decrease in corn (mean of 30\%) and an increase in alfalfa (mean of 37\%) due to the installation of a new alfalfa hay processing plant in Almudévar in 2000. During 2005-2008 a sharp reduction in corn (mean of 5\%) along with an increment in winter grains (mean of 30\%) took place due to water limitations, 
particularly in 2005, and the on-going irrigation modernization. The relatively low irrigated and high not cultivated areas in 1999 and 2005 were due to water restrictions, whereas those in 2008 were due to an intensification of the modernization works in this year.

\section{Materials and methods}

\subsection{Irrigation season and monthly irrigation performance indices for VID}

In part I of this work (Barros et al., 201x), the VID water balance components were calculated on a monthly basis for each 1995 to 2008 hydrological year. This monthly values, expressed in volume of water per unit of irrigated land (mm), were aggregated to obtain the main water balance components for the 1995-2008 April to September irrigation seasons (Fig. 3).

Based on these irrigation season and monthly values, the following irrigation performance indices were calculated for each 1995-2008 study year:

(1) Relative water deficit (RWD), percent difference between the maximum $\left(E T_{c}\right)$ and the actual $\left(E T_{a}\right)$ crop evapotranspiration over the maximum $E T_{c}$ :

$$
\mathrm{RWD}=100 \cdot \frac{E T_{c}-E T_{a}}{E T_{c}}
$$

The RWD for a given crop is linearly related to the relative reduction in crop yield (Doorenbos and Kassam, 1979).

(2) Irrigation consumptive use coefficient (ICUC; Burt et al., 1997), percent ratio of the volume of irrigation water consumptively used (CU) to the irrigation water available for the consumption of crops: 


$$
\mathrm{ICUC}=100 \cdot \frac{E T_{a}-P_{e}}{I-\Delta W_{s}}
$$

where $\mathrm{CU}=E T_{a}-P_{e}\left(P_{e}\right.$ is the effective precipitation defined below that is discounted from $E T_{a}$ to take into account only the consumptive use of crops arising from irrigation), $I=$ irrigation, and $\Delta W_{s}=$ change in soil water content for the study period. A theoretical ICUC of $100 \%$ would indicate that the volume of irrigation applied (plus the decrease in soil water content) was used completely for crop transpiration (consumptive use).

(3) Drainage fraction (DRF): percent ratio of the irrigation return flows $\left(Q^{*}\right)$ to the total water delivered to the system $(I+P)$ :

$$
\mathrm{DRF}=100 \cdot \frac{Q^{*}}{I+P}
$$

where $Q^{*}$ is the outflow minus the lateral inflows to the gully (Barros et al., 201x). Since virtually all $Q^{*}$ generated in VID is collected in La Violada gully and is reused downstream, DRF is equivalent to the recoverable runoff/percolation fraction defined by Lecina et al. (2010) and Perry (2011).

All the terms in these equations were presented and discussed in Barros et al. (201x), except the effective precipitation $\left(P_{e}\right)$ that was estimated from the daily soil water balance, thus taking into account actual management practices (irrigation scheduling and applied volumes) and average soil properties:

(a) In days when $P$ is the only water input to the soil, $P_{e}$ was calculated as:

$$
\begin{array}{ccc}
P_{e}=P & \text { if } & W_{s}+P<F C \\
P_{e}=F C-W_{s} & \text { if } & W_{s}+P>F C
\end{array}
$$


where $W_{s}$ is the soil water content and $F C$ is field capacity. Playán et al. (2000) estimated an average $F C$ of $294 \mathrm{~mm}$ and an average permanent wilting point $(W P)$ of $199 \mathrm{~mm}$ for the soils in the district.

(b) In days when both $I$ and $P$ take place, $P_{e}$ was calculated as:

$$
P_{e}=P \cdot \frac{\left(F C-W_{s}\right)}{I+P}
$$

In addition to these irrigation performance indices, the crop's net irrigation requirement (NIR) or irrigation water needed to fully satisfy crop water needs (Krinner et al. 1994) was calculated as:

$$
\mathrm{NIR}=E T_{c}-P_{e}
$$

\subsection{Irrigation season performance indices for each crop}

The average 1995-2008 irrigation season performance indices were calculated for the three most important crops grown in VID (corn, alfalfa and winter grain) and for sunflower because of its unique management. The growing periods (sowing to harvesting dates) for each crop were taken from Allen et al. (1998) and from interviews to farmers, except in corn where the beginning of the growing period was taken as 1 April (i.e., before sowing in 20 April) to include the usual pre-sowing irrigations given in VID in the 1990’s (Isidoro et al. 2004).

The water balance terms used to calculate these indices were $I_{S}$ (irrigation established by the average irrigation calendar), $D$ (drainage or excess water above field capacity) $E T_{c}, E T_{a}, P_{e}$ and $\Delta W_{s}$ along the growing period of each crop. These terms were established through daily soil water balances performed for each crop (Barros et al., 201x) based on the actual soil properties in VID (Playán et al., 2000), the irrigation 
depths and schedules obtained in farmers interviews (Isidoro et al. 2004; Barros et al. 201x) and the analysis of water delivery records (Faci et al. 2000) (Table 1).

\section{Results and discussion}

\subsection{Irrigation season water balances}

Figure 3 summarizes the main inputs (irrigation $I$, precipitation $P$, and canal seepage $C S$ ) and outputs (outflow in La Violada gully originating from the irrigated land $Q^{*}$ and actual crops evapotranspiration $E T_{a}$ ) of the water balances performed in the 1995-2008 irrigation seasons and its 1995-2008 average plus one standard deviation. The major input in all years was $I$, with a 1995-2008 average of $756 \mathrm{~mm}$, equivalent to $67 \%$ of total inputs. With some exceptions, the second major input was $P$, with an average of $231 \mathrm{~mm}$, equivalent to $20 \%$ of total inputs. $C S$ values were around $200 \mathrm{~mm}$ in the 1998-2002 period, and decreased to values below or around $100 \mathrm{~mm}$ in the 20032008 period. The average $C S$ was $131 \mathrm{~mm}$, equivalent to $12 \%$ of total inputs. The term other inputs $(O I=$ surface runoff + canal releases + municipal wastewaters $)$, not shown in Fig. 3, was low in all years, with an average of $40 \mathrm{~mm}$, equivalent to $4 \%$ of total inputs.

Total 1995-2008 input average was $1130 \pm 225 \mathrm{~mm}$ (mean \pm standard deviation), with significant differences $(\mathrm{P}<0.001)$ in 1995-2004 (1250 mm average) and 2005-2008 (832 mm average). The main reasons for the lower 2005-2008 total input were (i) lower irrigation volumes due to water shortages in 2005 and 2006, (ii) a shift in crop patterns from high (corn and alfalfa) to low (winter grains) water-demanding crops (Fig. 2), (iii) lower canal seepages due to the new elevated Violada canal operative in 2003, and (iv) higher not cultivated land in 2008 (Fig. 2) due to an intensification of modernization works. 
Total 1995-2008 output average was $1188 \pm 257 \mathrm{~mm}$, with $581 \mathrm{~mm}$ for $Q^{*}$ (49\% of total) and $566 \mathrm{~mm}$ for $E T_{a}$ (48\% of total) (Fig. 3). Total outputs were also significantly different $(\mathrm{P}<0.001)$ in 1995-2004 (1326 mm) and 2005-2008 (843 mm). The lower 2005-2008 outputs were due to lower drainage volumes derived from the already mentioned lower inputs, and lower $E T_{a}$ due to a shift from corn to winter grains and a higher proportion of not cultivated land.

The 1998-2008 irrigation season average change in soil water content $\left(\Delta W_{s}\right)$ was $-29 \pm 26 \mathrm{~mm}$, a minor value compared to the rest of terms in the equations where this variable was included.

All the irrigation season water balance errors were lower than $10 \%$, except in 1995 (-20\%) and $1996(-16 \%)$, two of the three years without $C S$ estimates. The 19952008 average error was $-51 \mathrm{~mm}$, equivalent to $-4 \%$ of total outputs. This low error gives confidence to the estimated water balance terms and allows for a sensible assessment of irrigation performance in VID.

\subsection{Irrigation season performance indices}

Fig. 4 shows the NIR, consumptive use (CU) and the performance indices RWD, ICUC and DRF calculated in each 1995-2008 irrigation season. The 1995-2008 average NIR was $537 \pm 88 \mathrm{~mm}$. Variability among years (Fig. 4a) was associated to variability in cropping patterns and effective precipitation. The lowest NIR values were found in years predominant in winter grains (2007 and 2008, Fig. 2) and in year 1997, when $P_{e}$ reached a maximum value of $245 \mathrm{~mm}$. In contrast, high NIR values were obtained in years with low seasonal $P_{e}$ as 1995 (97 mm), $1998(132 \mathrm{~mm})$ and $2001(113 \mathrm{~mm})$.

The 1995-2008 average relative water deficit (RWD) was high (20 $\pm 6 \%$, indicating that the available water was insufficient to meet the maximum $E T_{c}$ even 
though the volumes of irrigation were higher than the NIR. The highest RWD values occurred in the last years (except in 2008, the year with the lowest irrigated area due to intensification of modernization works) due to irrigation restrictions, especially in the driest 2005 year (Fig. 4b). The lowest RWD values occurred in the nineties, years with highest irrigation and precipitation volumes (Fig. 3). The high RWD values found in VID showed that water stress was significant, particularly in drought years, a constraint that should be alleviated with the on-going transformation of irrigation into sprinkler systems.

The 1995-2008 average irrigation consumptive use coefficient (ICUC) was 51\%, and the highest ICUC (67\%) was attained in the drought 2005 year (Fig. 4c). The intense reuse of drainage waters for irrigation in 2005 and 2006 also explains their high ICUC values, since the actual volume of water delivered to the fields was significantly higher than the volume billed by CRA. Nevertheless, these ICUC values were very low compared to SIPI values of 92\% (Tedeschi et al. 2001) and 94\% (Cavero et al. 2003) found in sprinkler-irrigated districts of the middle Ebro River Basin. Previous works (Playán et al. 2000) point to the shift from surface to sprinkler irrigated systems to increase SIPI in VID.

The 1995-2008 average drainage fraction (DRF) was very high (57\%) and significantly $(\mathrm{P}<0.005)$ higher in 1995-2002 $(\mathrm{DRF}=63 \%)$ than in 2003-2008 $(\mathrm{DRF}=49 \%)($ Fig. 4d). An important reason for the lower DRF in the last period was the entrance in operation of the new elevated La Violada canal in 2003 that eliminated the high seepage $(C S)$ of the old canal. Thus, discounting $C S$ in the calculation of DRF, the 1998-2008 average DRF was 41\% and without significant differences between these periods. The lowest DRF of 30\% obtained in 2005 was consistent with the intense drainage water reuse of about $65 \mathrm{~mm}$ and a lower applied irrigation volume in this year. 
The irrigation season performance indices obtained in the fourteen-years study period showed that irrigation management in VID was poor, mainly due to the high irrigation depths given to relatively low water-retention soils (95 $\mathrm{mm}$ according to Playán et al. 2000). The low average ICUC (51\%), pointed to an inadequate irrigation management in VID. The drought and the intense reuse of drainage waters in 2005 and 2006 led to higher ICUC and reduced DRF. However, RWD did not decrease, but reached its maxima (33\% in 2005 and 30\% in 2006) showing that higher ICUC did not imply a better water use.

The high RWD values found in VID were mostly due to fixed irrigation schedules imposed by an insufficient capacity of the irrigation distribution network (Faci et al. 2000). The construction of the internal reservoirs could reduce RWD by providing a higher irrigation flexibility (i.e., decreased irrigation intervals and proper timings of irrigation to each crop) if they were accompanied by an increase in the capacity of the irrigation ditches. However, only four reservoirs with a total capacity of $0.2 \mathrm{hm}^{3}$ (accounting for 37\% of the total storage capacity) were in operation since 1998, and the capacity of the irrigation ditches has not been increased. The change to sprinkler irrigation systems, where irrigation depths and dates can be established by the system's managers, along with the construction of the two remaining largest internal reservoirs (total capacity of $0.6 \mathrm{hm}^{3}$ ) should provide for an increase in irrigation efficiencies and a decrease in crop’s water deficits.

As previously indicated, a significant infrastructure improvement has been the construction of the new elevated Violada canal that entered in service in 2003. As compared with the old and deteriorated Violada canal, the new canal reduced the amount of seepage $(C S)$ by an average of $38 \%$, equivalent to a conservation of water in the canal of $5.0 \mathrm{Mm}^{3}$ in the irrigation season and $6.1 \mathrm{Mm}^{3}$ in the hydrological year 
(Barros et al. 201x). These lower seepages significantly reduced DRF after 2003, and further decreases are expected following the modernization of the irrigation system because of the inherent higher irrigation efficiencies of the new sprinkler systems.

Increased irrigation efficiencies will have important benefits within VID because the volume of water allocated and its cost to farmers will decrease. In contrast, the corresponding decreases in drainage fractions will decrease the volume of water in La Violada gully, a recoverable resource that is beneficially used downstream. Hence, savings of water in the Gállego river basin will be negligible. This conclusion has been substantiated in previous works that showed that increased irrigation efficiencies have a minor impact in water conservation at the watershed scale, and that this concept is not appropriate for assessing the hydrological impact of irrigation at the watershed scale (Willardson et al., 1994; Perry, 1999; Perry et al., 2009; Jensen, 2007; Lecina et al., 2010; Perry, 2011).

Nevertheless, increasing irrigation efficiencies in VID will have an additional off-site benefit from the point of view of water quality. The soils in VID are high in gypsum, so that salinity in drainage waters is relatively constant and close to gypsum saturation (Faci et al. 1985). Hence, the mass of salts exported through La Violada gully to the Gállego river are almost proportional to the volume of drainage waters (Isidoro et al. 2006a) that will decrease with higher irrigation efficiencies. The final result would be that water quality in the Gállego river downstream of La Violada gully will benefit from these reduced salt loads. The low actual irrigation efficiencies and low salt concentrations in irrigation water $\left(\mathrm{EC}<0.4 \mathrm{dS} \mathrm{m}^{-1}\right)$ allow to increase these efficiencies without compromising crop yields due to root-zone salt stress. Also, the quality of the non-diverted or non-seeped water is conserved and maintains the high quality of the 
irrigation water because it is not mixed with the low quality drainage waters in La Violada gully.

\subsection{Monthly irrigation performance indices}

The 1995-2008 monthly averages of $I, P, E T_{c}, E T_{a}$, NIR, and the irrigation performance indices RWD, ICUC and DRF are presented in Figure 5. The lowest $I$ were found at the beginning (April and May) and end (September) of the irrigation season (Fig. 5a), when $E T_{c}, E T_{a}$ and NIR were also lowest (Figs. 5b, c). The highest irrigation volumes were given in June, July and August, the months with maximum alfalfa and corn development, maximum $E T_{a}$ and maximum NIR. The average crop water deficit $\left(E T_{c}-E T_{a}\right)$ was $24 \mathrm{~mm} / \mathrm{month}$, with the highest values found in April $\left(E T_{c}-E T_{a}=44\right.$ $\mathrm{mm}$ ) following the insufficient irrigation given to winter cereals in some years.

The lowest ICUC was obtained in April (35\%), when corn with a very low $E T_{a}$ was generally irrigated to obtain soil water contents adequate for sowing, promote its emergence and stand establishment, and minimize soil crusting These pre-sowing (and post-sowing) corn irrigations were very high due to the limitations of the irrigation system, leading to enhanced drainage and lower consumptive fraction (Fig. 5c). ICUC in May increased to a value of $57 \%$ because corn was generally not irrigated (and thus $I$ was lower; Fig. 5a), and the crop used the water previously stored in the soil from the April irrigations. The combination of monthly ICUC estimations with the $I$ (Fig. 5a) and $E T_{a}$ (Fig. 5b) observations in April and May reveal the crop use in May of the soil water storage derived from this excess April applications. The highest variability in April ICUC (Fig. 5e) follows from the halt in the use of this high volume pre-sowing irrigation after 2000, with the introduction of new sowing techniques. High volume pre- 
sowing irrigation was thus an avoidable practice leading to high drainage volumes in April and to the leaching of the $\mathrm{N}$ fertilizer applied at pre-sowing (Isidoro et al., 2006b).

ICUC remained relative constant in June-August and decreased in September, when irrigation was about $90 \mathrm{~mm}$ whereas NIR was below $50 \mathrm{~mm}$. It is expected that sprinkler irrigation will increase ICUC in VID, particularly in April, because lower irrigation depths will be attainable to minimize soil crusting.

The monthly DRF values were high, nearly constant and close to $60 \%$ along April to August, and increased to 70\% in September (Fig 5f) due to the discharge of the aquifer to La Violada Gully along this month (Barros et al. 201x). These high DRF monthly values reflect the actual poor irrigation management in VID.

\subsection{Crop's irrigation performance indices}

Table 2 summarizes the 1995-2008 irrigation season average volumes of irrigation $\left(I_{s}\right)$, evapotranspiration $\left(E T_{c}\right.$ and $\left.E T_{a}\right)$, net irrigation requirement (NIR), consumptive use of water (CU), and the RWD, ICUC and DRF irrigation performance indices for the most important crops grown in VID (corn, alfalfa and winter grains) and for sunflower. The volumes of $I_{s}, \mathrm{ET}_{c}, E T_{a}$ and NIR were highest in alfalfa, the crop with the longest growing season (Table 1), followed by corn, sunflower and winter grains. Winter grains presented the highest irrigation standard deviation because water availability in spring was affected by the spring rains and the number of irrigations, both quite variable between years. In years with water scarcity (as 2005), a normal practice was to apply one or no irrigation to winter grains. The same occurred in 2008 with the irrigation transformation works: farmers preponderantly cultivated winter grains that could not be fully irrigated. The relatively high $I_{s}$ standard deviation in corn was mainly due to the irrigation applications in April mainly in the early years of the study period. 
Corn had the lowest relative water deficit (14\%) and sunflower the highest (44\%), whereas the rest of crops had intermediate values (24-27\%). Yield decreases are assumed to be proportional to water deficits through the yield response factor $k_{y}$ ( 0.9 for alfalfa, 1.25 for corn, 1.0 for winter grains and 0.95 for sunflower; Doorenbos and Kassam 1979). Based on water deficits and these yield response factors, the actual yields were 76\% (alfalfa), 82\% (corn) and 76\% (winter grains) of potential yields under no water stress. Since corn is most sensitive to water stress (highest $k_{y}$ ) and has the highest production costs, farmers applied water preferentially to this crop to minimize RWD and yield losses. In contrast, sunflower had the highest RWD, with actual yields as low as $58 \%$ of potential yields, because the benefits of this crop arise mainly from subsidies established by the European Agricultural Policy (EAP) that does not take yields into account. For this reason, the so-called "EAP-sunflower" was poorly irrigated and fertilized to minimize costs and obtain the maximum net benefits from their subsidies.

Corn had the highest ICUC (53\%), a value representative of those found in the middle Ebro River basin for surface irrigation (Faci et al. 2000). Alfalfa had the lowest ICUC (41\%) because the average irrigation depth was much higher than its water requirements (Table 2). DRF was highest in alfalfa and sunflower (52\%) and lowest in winter grains (34\%).

\section{Conclusions}

The water balances performed in the surface-irrigated La Violada Irrigation District (VID) along fourteen irrigation seasons (years 1995 to 2008) closed with yearly errors below $10 \%$ in most years, giving confidence to the water balance terms and allowing for a sensible assessment of irrigation performance in VID. 
Total inputs decreased significantly $(\mathrm{P}<0.001)$ during the last study years (20052008) due to water shortages in 2005 and 2006, a shift from high (corn and alfalfa) to low (winter grains) water-demanding crops, lower canal seepages due to the new elevated Violada canal operative in 2003, and higher non-cultivated land due to the 2008 irrigation modernization works.

Total outputs also decreased significantly in 2005-2008 due to lower inputs, lower drainage due to decreased canal seepages, an intensification of drainage water reuse in some water-shortage years, and lower crop water demands due to a shift from corn to winter grains and a higher proportion of non-cultivated land. In particular, the new elevated Violada canal was a sound investment since it eliminated seepages equivalent to $5.0 \mathrm{Mm}^{3}$ of water (i.e., $18 \%$ of the mean irrigation volume) during the irrigation season. Since these seepages result in increasing flows in La Violada gully that could be beneficially used downstream (i.e., recoverable losses), its suppression did not entail an increase in water availability at the watershed scale. However, the decreased seepages from La Violada Canal preserved the quality of the overall water resources in the Gállego basin.

The seasonal-average irrigation performance indices indicate that irrigation management was poor, with low irrigation consumptive use coefficient (ICUC) and high relative water deficit (RWD) and drainage fraction (DRF) values due to high irrigation depths and fixed irrigation schedules given to the relatively low soil-water holding capacity VID soils. The highest ICUC values in 2005 and 2006 were coupled to highest RWD, showing that higher irrigation efficiencies were linked to higher crop water deficits in these water-shortage years. 
The monthly irrigation performance indices show that April was the month with the poorest irrigation management (i.e., highest RWD and lowest ICUC) because corn, with negligible water demands in this month, was irrigated in some years to minimize soil crusting and promote its emergence and plant establishment, whereas winter grains, with high water demands in this month, were not fully irrigated in water-shortage years. The new sprinkler systems being installed in VID should drastically ameliorate irrigation management in April by decreasing irrigation depths in corn that will increase ICUC, and by increasing irrigation in winter cereals that will decrease RWD.

The crop's irrigation performance indices show that sunflower had the highest RWD because its profit arises from European subsidies rather than from yield benefits. Corn was the best irrigated crop (relatively low RWD and DRF, and high ICUC) because farmers preferentially irrigate this sensitive crop to water stress to maximize yields and economic returns. In contrast, alfalfa was poorly irrigated and about half of the water applied was lost as drainage, emphasizing for the need to reduce irrigation depths and accommodate irrigation intervals to alfalfa water needs.

The long-term series irrigation performance data along with irrigation management information allowed establishing cause-effect relationships. The entrance in operation of all the internal reservoirs and the change to sprinkler irrigation systems following year 2008 would increase irrigation efficiencies and decrease crop water deficits in VID. Although these modernization works will not imply water savings at the watershed scale, they would lead to a more efficient irrigation management; lower water allocated to VID, higher farmer's revenues, lower drainage outflows and salt loads, and improved water quality in the Gállego river that will benefit downstream users. 


\section{Acknowledgements}

The authors thank the Almudévar Water User Association (Comunidad de Regantes de Almudévar) and the Ebro River Basin Authority (Confederación Hidrográfica del Ebro) for their support and cooperation. This work was sponsored by the Spanish Ministry of Science and Education project AGL2006-11860/AGR, the European Regional Development Fund (FEDER) and the European Union project Qualiwater (INCO CT-2005-015031).

\section{References}

Allen, R.G., Pereira, L.S., Raes, D., Smith, M., 1998. Crop evapotranspirationguidelines for computing crop water requirements. FAO Irrig. Drain. Paper 56, Rome, Italy.

Barros, R., Isidoro, D., Aragüés, R., 201x. Long-term water balances in La Violada Irrigation District (Spain): I. Sequential assessment of main inputs, outputs and water balance closing errors. Agric. Water Manage. (companion paper).

Bos, M.G., Murray-Rust, D.H., Merrey, D.J., Johnson, H.G., Snellen, W.B., 1994. Methodologies for assessing performance of irrigation and drainage management. Irrig. Drain. Syst. 7, 231-261.

Bos, M.G., Nugteren, J., 1990. On irrigation efficiencies. $4^{\text {th }}$ edition (1 $1^{\text {st }}$ edition 1974$)$. International Institute for land reclamation and improvement/ILRI Publication 19, Wageningen.

Burt, C.M., Clemmens, A.J., Strelkoff, T.S., Solomon, K.H., Bliesner, R.D., 1997. Irrigation performance measures: efficiency and uniformity. J. Irrig. Drain. Eng. 123(6), 423-442. 
Cavero, J., Beltrán, A., Aragüés, R., 2003. Nitrate exported in the drainage water of two sprinkler irrigated watersheds. J. Environ. Qual. 32, 916-926.

Connor, D.J., Jones, T.R., 1985. Response of Sunflower to Strategies of Irrigation. 2. Morphological and Physiological-Responses to Water-Stress. Field Crops Res. 12(2), 91-103.

Dechmi, F., Playan, E., Faci, J.M., Tejero, M., 2003. Analysis of an irrigation district in northeastern Spain I. Characterisation and water use assessment. Agric. Water Manage. 61 (2), 75-92.

Doorenbos, J., Kassam, A.H., 1979. Yield response to water. U.N. FAO Irrig. and Drain Paper 33, Rome, Italy.

Faci, J., Aragüés, R., Alberto, F., Quilez, D., Machin, J., Arrue, J.L., 1985. Water and salt balance in an irrigated area of the Ebro River Basin (Spain). Irrig. Sci. 6, 29-37.

Faci, J.M., Bensaci, A., Slatni, A., Playán, E., 2000. A case study for irrigation modernisation I. Characterisation of the district and analysis of water delivery records. Agric. Water Manage. 42, 313-334.

García-Garizábal, I., Valenzuela, J.C., Abrahao, R., 2009. Evolution of the efficiency and agro-environmental impact of a traditional irrigation land in the middle Ebro Valley (2001-2007). Span J. Agric. Res. 7(2), 465-473.

Haie, N., Keller, A.A., 2008. Effective efficiency as a tool for sustainable water resources management. J. Am. Water Resour. Assoc. 44(4), 961-968.

Hanson, B., Putnam, D., Snyder, R., 2007. Deficit irrigation of alfalfa as a strategy for providing water for water-short areas. Agric. Water Manage. 9, 373-80. 
Humphreys, E., Meisner, C., Gupta, R., Timsina, J., Beecher, H.G., Lu, T.Y., Yadvinder, S., Gill, M.A., Masih, I., Guo, Z.J., Thompson, J.A. 2005. Water saving in rice-wheat systems. Plant Prod. Sci. 8 (3), 242-258.

Isidoro, D., Quílez, D., Aragüés, R. 2004. Water balance and irrigation performance analysis: La Violada irrigation district (Spain) as a case study. Agric. Water Manage. 64, 123-142.

Isidoro, D., Aragüés, R. 2006, A twenty-year trend analysis of salt and nitrogen mass balances and export loads in La Violada irrigation district (Spain), International Symposium on Water and Land Management for Sustainable Irrigated Agriculture: Çukurova University, Adana (Turkey), 4-8 April 2006.

Isidoro, D., Quílez, D., Aragüés, R. 2006a. Environmental impact of irrigation in La Violada district (Spain): Salt export patterns. J. Environ. Qual. 35, 766-775.

Isidoro, D., Quílez, D., Aragüés, R. 2006b. Environmental impact of irrigation in La Violada district (Spain): II: Nitrogen fertilization and nitrate export patterns in drainage waters, Journal of Environmental Quality 35 (3): 776-785.

Israelsen, O.W., Hansen, V.E., 1962. Irrigation principles and practices. Jonh Wiley and Sons, Inc. $3^{\text {rd }}$ edition. New York.

ITGE, 1995. Mapa geológico de España escala 1:50000. Instituto Tecnológico Geominero de España, Almudévar, Spain.

Jensen, M.E., 2007. Beyond irrigation efficiency. Irrig. Sci. 25(3), 233-245. 
Karatas, B.S., Akkuzu, E., Unal, H.B., Asik, S., Avci, M., 2009. Using satellite remote sensing to assess irrigation performance in Water User Associations in the Lower Gediz Basin, Turkey. Agric. Water Manage. 96(6), 982-990.

Keller, A.A., Keller, J., 1995. Effective efficiency: A water use efficiency concept for allocating freshwater resources. Winrock International Water Resources and Irrigation Division, Discussion Paper 22. Arlington, Virginia.

Krinner, W., García, A., Estrada, F. 1994. Method for estimating efficiency in Spanish irrigation systems. J. Irrig. Drain Eng. 120 (5), 979-985.

Lecina, S., Playan, E., Isidoro, D., Dechmi, F., Causape, J., Faci, J.M., 2005. Irrigation evaluation and simulation at the irrigation District V of Bardenas (Spain). Agric. Water Manage. 73 (3), 223-245.

Lecina, S., Isidoro, D., Playán, E., Aragüés, R., 2010. Irrigation Modernization and Water Conservation in Spain: The Case of Riegos del Alto Aragón. Agric. Water Manage. 97, 1663-1675.

Lorite, I.J., Mateos, L., Orgaz, F., Fereres, E., 2007. Assessing deficit irrigation strategies at the level of an irrigation district. Agric. Water Manage. 91(1-3), 51-60.

MARM, 2010 http://www.mapa.es/es/desarrollo/pags/pnr/principal.htm. Accessed 14 May 2010.

Molden D., 1997 Accounting for Water Use and Productivity. SWIM Paper 1. International Irrigation Management Institute. Colombo, Sri Lanka.

Molden, D., Sakthivadivel, R., 1999. Water accounting to assess use and productivity of water. Water Resour. Dev. 15(1/2), 55-71. 
Perry, C.J., 1999. The IWMI water resources paradigm—definitions and implications. Agric. Wat. Manage. 40 (1), 45-50.

Perry, C., Steduto, P., Allen, R.G., Burt, C.M., 2009. Increasing productivity in irrigated agriculture: Agronomic constraints and hydrological realities. Agric. Water Manage. 96 (11), 1517-1524.

Perry, C, 2011. Accounting for water use: terminology and implications for saving water and increasing production. Agric. Water Manage. (in press).

Playán, E., Slatni, A., Castillo, R., Faci, J.M., 2000. A case study for irrigation modernisation: II Scenario analysis. Agric. Water Manage. 42, 335-354.

Rao, P.S., 1993. Review of selected literature on indicators of irrigation performance. International Irrigation Management Institute, Colombo.

Seckler, D., Molden, D., Sakthivadivel, R., 2003. The concept of efficiency in waterresources management and policy. In: Kijne W, Barkers R, Molden D. (eds) Water productivity in Agriculture: limits and opportunities for improvement. CAB International, Wallingford, UK, pp 37-51.

Tedeschi, A., Beltrán, A., Aragüés, R., 2001. Irrigation management and hydrosalinity balance in a semi-arid area of the middle Ebro river basin (Spain). Agric. Water Manag. 49, 31-50.

Willardson, L.S., Allen, R.G., Frederiksen, H.D., 1994. Elimination of irrigation efficiencies. In: Proceedings of the 13th Technical Conference USCID, USCID (Ed.), Denver (CO), USA, p. 17. 
Table 1. Mean \pm standard deviation values of the average irrigation calendar (number of irrigations, depth of each irrigation, irrigation interval, and date of first irrigation), sowing and harvesting dates and length of the growing season used in the soil water balances for the main crops grown in VID.

\begin{tabular}{|c|c|c|c|c|c|c|c|}
\hline & \multicolumn{4}{|c|}{ Irrigation } & \multicolumn{2}{|c|}{ Dates } & \multirow{2}{*}{$\begin{array}{c}\text { Length of } \\
\text { growing } \\
\text { season (days) }\end{array}$} \\
\hline & $\begin{array}{c}\text { Num } \\
\text { ber }\end{array}$ & $\begin{array}{l}\text { Depth } \\
(\mathrm{mm})\end{array}$ & $\begin{array}{c}\text { Interval } \\
\text { (days) }\end{array}$ & $\begin{array}{l}\text { Date of first } \\
\text { irrig. }\end{array}$ & $\begin{array}{l}\text { Sowi } \\
\text { ng }\end{array}$ & $\begin{array}{l}\text { Harvest } \\
\text { ing }\end{array}$ & \\
\hline Corn & $9 \pm 1$ & $110 \pm 20$ & $13 \pm 1$ & 14-Apr \pm 21 & $\begin{array}{l}20- \\
\text { Apr }\end{array}$ & 07-Oct & 170 \\
\hline Alfalfa* & $10 \pm 1$ & $130 \pm 30$ & $13 \pm 1$ & 30-Mar \pm 15 & $\begin{array}{l}15- \\
\text { Mar }\end{array}$ & 20-Nov & 250 \\
\hline $\begin{array}{l}\text { Winter } \\
\text { grains }\end{array}$ & $1 \pm 1$ & $150 \pm 10$ & $30-40$ & $16-M a r \pm 10$ & $\begin{array}{l}01- \\
\text { Nov }\end{array}$ & 5-Jun & 217 \\
\hline $\begin{array}{l}\text { Sunflowe } \\
\mathrm{r}\end{array}$ & 3 & $150 \pm 50$ & 30 & 20-May \pm 10 & $\begin{array}{l}\text { 15- } \\
\text { Apr }\end{array}$ & 12-Sep & 133 \\
\hline
\end{tabular}

* For alfalfa, the sowing and harvesting dates correspond to the beginning and end of the vegetative period 
Table 2. 1995-2008 mean \pm standard deviation values of irrigation established by the average irrigation calendar $\left(I_{s}\right)$, maximum crop evapotranspiration $\left(E T_{c}\right)$, actual crop evapotranspiration $\left(E T_{a}\right)$, net irrigation requirements (NIR), consumptive use of irrigation water (CU), relative water deficit (RWD), irrigation consumptive use coefficient (ICUC) and drainage fraction (DRF), for the main crops grown in VID.

\begin{tabular}{lcccccccc}
\hline & & & & & & \multicolumn{3}{c}{ ICU } \\
& $\boldsymbol{I}_{\boldsymbol{s}}$ & $\boldsymbol{E T}_{\boldsymbol{c}}$ & $\begin{array}{c}\boldsymbol{E} \boldsymbol{T}_{\boldsymbol{a}} \\
\mathrm{mm}\end{array}$ & $\mathbf{N I R}$ & $\mathbf{C U}$ & $\mathbf{R W D}$ & $\begin{array}{c}\mathbf{C} \\
\%\end{array}$ & DRF \\
\hline \multirow{2}{*}{ Corn } & $990 \pm 14$ & & $707 \pm 3$ & & $538 \pm$ & & & \\
& 3 & $826 \pm 38$ & 6 & $657 \pm 65$ & 57 & $14 \pm 4$ & $53 \pm 7$ & $45 \pm 6$ \\
Alfalfa & $1163 \pm 8$ & $1006 \pm 6$ & $731 \pm 4$ & $760 \pm 11$ & $485 \pm$ & & & \\
Winter & 3 & 4 & 4 & 1 & 63 & $27 \pm 7$ & $41 \pm 3$ & $52 \pm 2$ \\
Grains & $236 \pm 15$ & & $408 \pm 5$ & & & & & \\
& 2 & $537 \pm 28$ & 2 & $293 \pm 68$ & $164 \pm 70$ & $24 \pm 9$ & $51 \pm 6$ & $34 \pm 13$ \\
Sunflower & $450 \pm 0$ & $688 \pm 35$ & 4 & $571 \pm 67$ & $265 \pm 12$ & $44 \pm 8$ & $50 \pm 2$ & $52 \pm 3$ \\
\hline
\end{tabular}




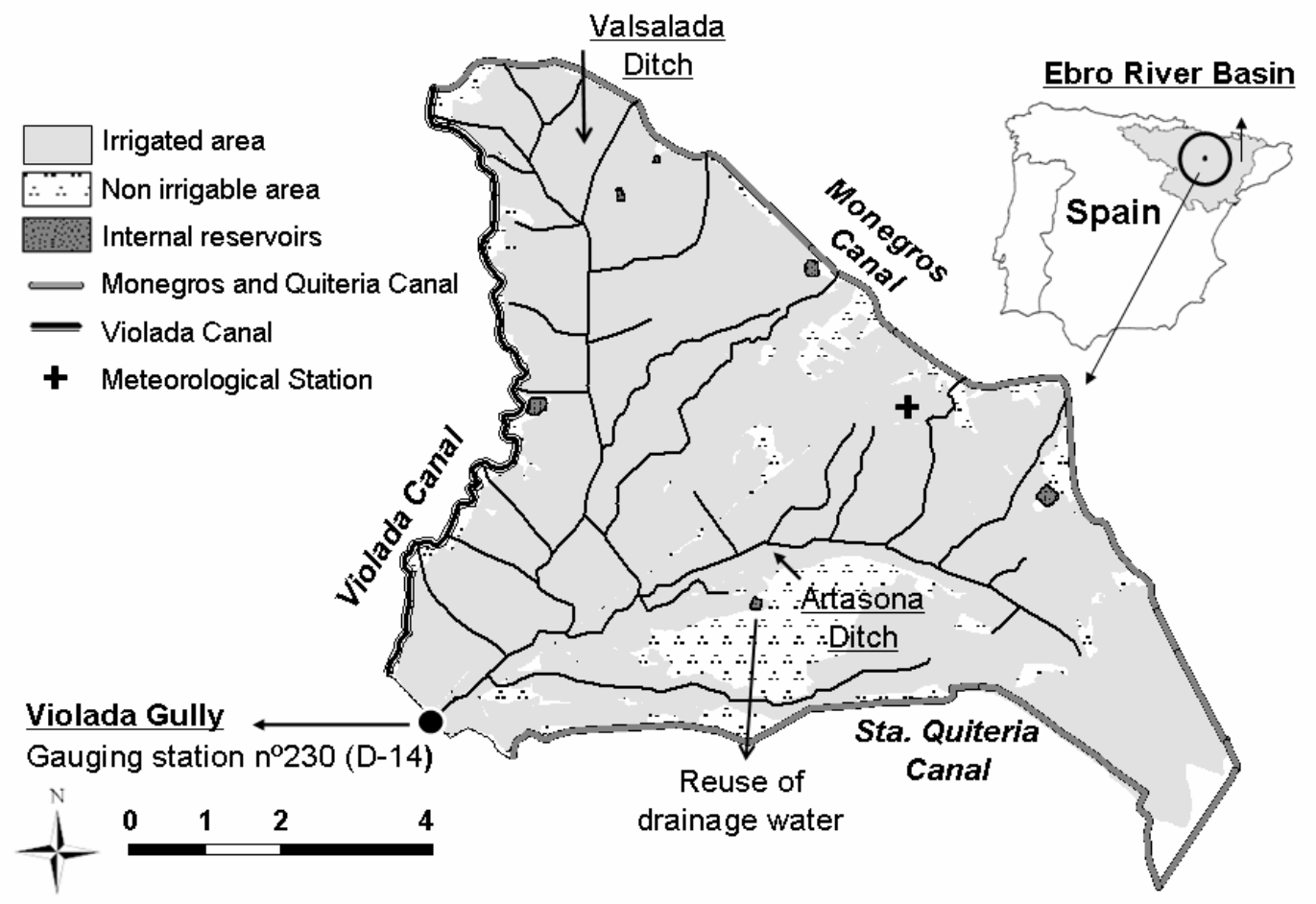

Figure 1. Location of La Violada Irrigation District (VID) in the middle Ebro river basin (Spain): Violada, Monegros and Sta. Quiteria Canals; drainage network and Valsalada and Artasona Ditches; Violada Gully and D-14 Gauging station; irrigable and non irrigable areas. The location of the internal reservoirs and meteorological station are also shown. 


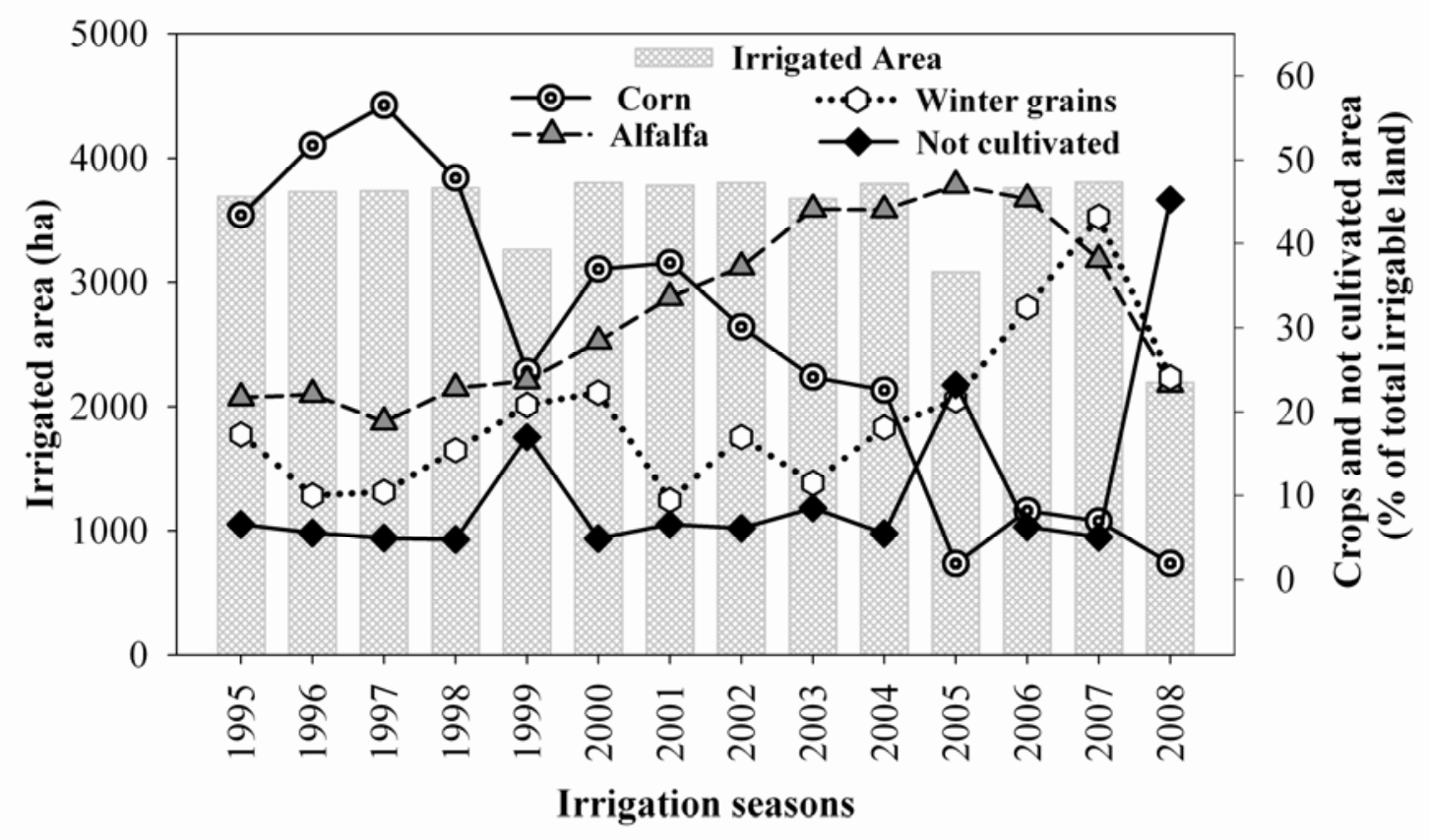

Figure 2. Irrigated area and distribution of main crops and not cultivated areas in VID for the 1995-2008 irrigation seasons. 


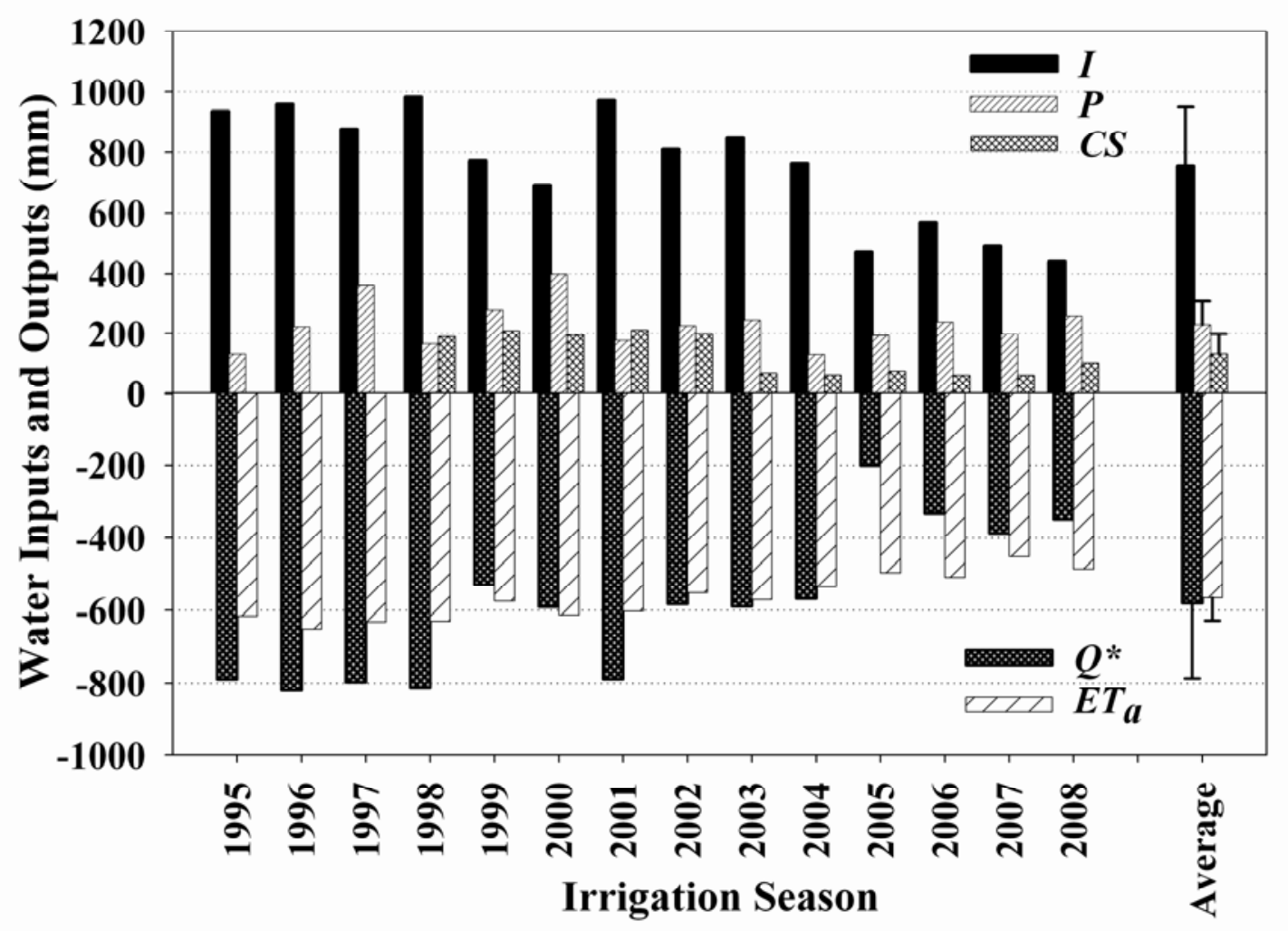

Figure 3. Main terms of the water balance for the 1995-2008 VID irrigation seasons: irrigation $(I)$, precipitation $(P)$ and canal seepage $(C S)$ expressed as positive inputs; outflow originating from the irrigated land $\left(Q^{*}\right)$ and actual crop evapotranspiration $\left(E T_{a}\right)$ expressed as negative outputs. Bars indicate one standard deviation of the 19952008 average values. 


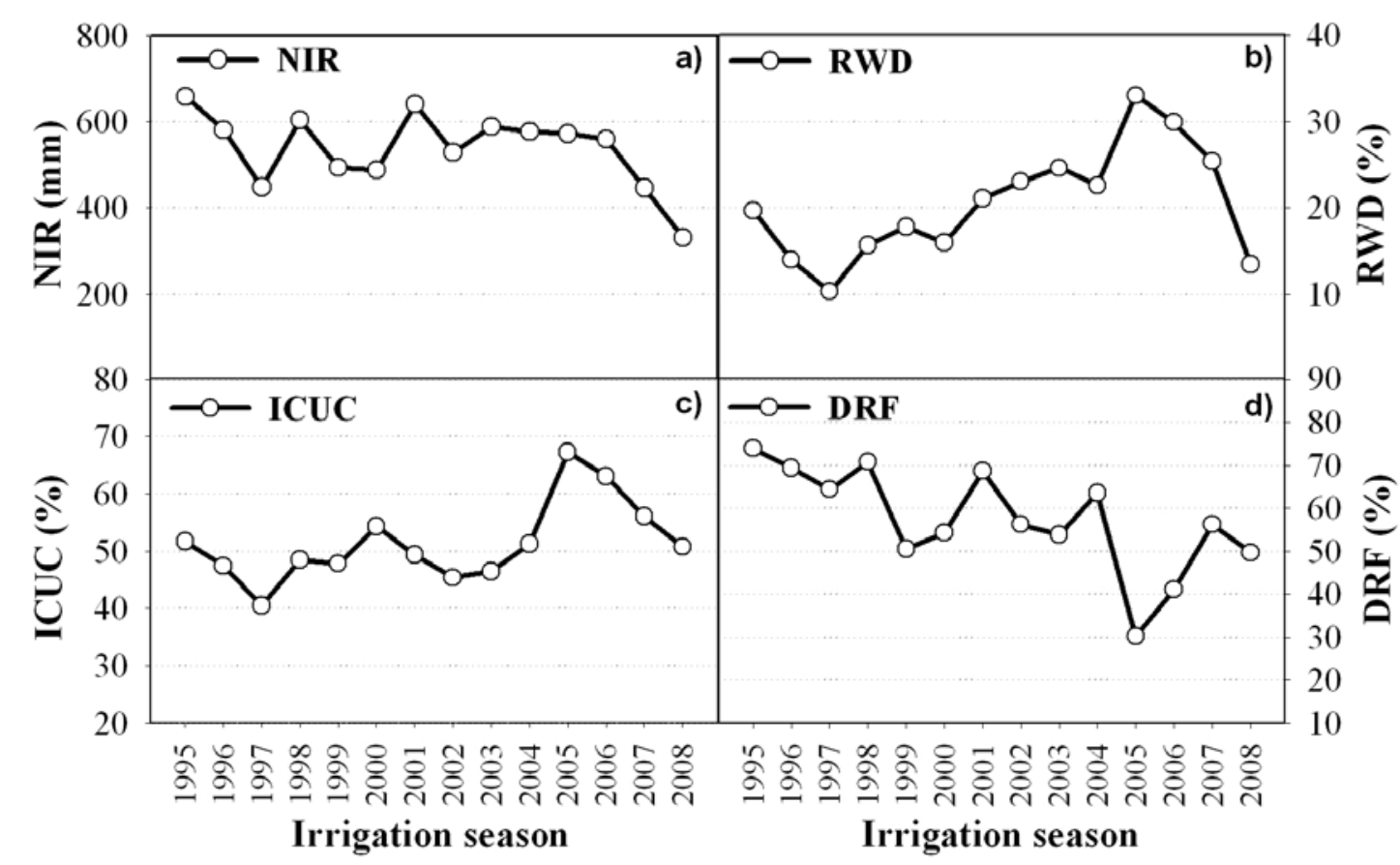

Figure 4. Net irrigation requirements (NIR) and irrigation performance indices for the 1995-2008 VID irrigation seasons: RWD = relative water deficit index; ICUC = irrigation consumptive use coefficient; DRF = drainage fraction index. 


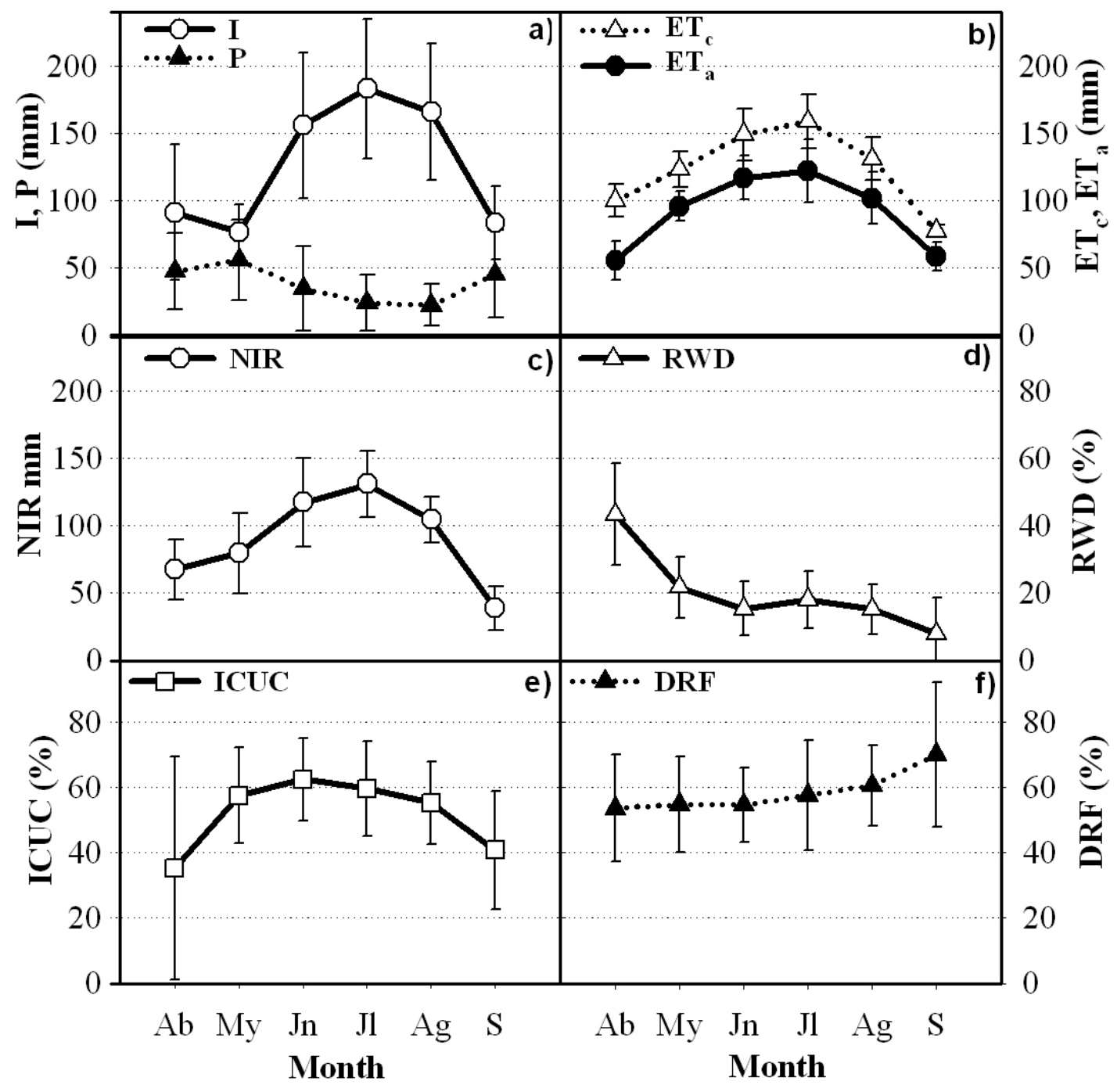

Figure 5. Monthly averages and standard deviations for the 1995-2008 VID irrigation seasons of: irrigation $(\mathrm{I})$, precipitation $(\mathrm{P})$, maximum crop evapotranspiration $\left(\mathrm{ET}_{\mathrm{c}}\right)$, actual crop evapotranspiration ( $\left(\mathrm{ET}_{\mathrm{a}}\right)$, net irrigation requirements (NIR) and the irrigation performance indices RWD, ICUC and DRF. 